medRxiv preprint doi: https://doi.org/10.1101/2021.12.26.21268422; this version posted December 29, 2021. The copyright holder for this preprint (which was not certified by peer review) is the author/funder, who has granted medRxiv a license to display the preprint in perpetuity.

It is made available under a CC-BY-NC-ND 4.0 International license .

\title{
Vitamin D Status \& Latitude Predict Brain Lesions in Adrenoleukodystrophy
}

Keith van Haren, $\mathrm{MD}^{1 *}$, Jacob Wilkes $B S,{ }^{2}$ Ann B. Moser $B A^{3}$, Gerald V. Raymond MD ${ }^{4,5}$, Troy Richardson $\mathrm{PhD}^{6}$, Patrick Aubourg MD ${ }^{7,8}$, Timothy W. Collins, $\mathrm{PhD}^{9}$, Ellen M Mowry MD, $\mathrm{MPH}^{4}$, and

$$
\text { Joshua L. Bonkowsky, MD, PhD 10-12 }
$$

${ }^{1}$ Division of Child Neurology, Department of Neurology, Stanford University, Palo Alto, California ${ }^{2}$ Intermountain Healthcare, Salt Lake City, Utah

${ }^{3}$ Peroxisomal Disease Laboratory, Kennedy Krieger Institute, Baltimore, Maryland

${ }^{4}$ Department of Neurology, Johns Hopkins University School of Medicine, Baltimore, Maryland

${ }^{5}$ Department of Genetic Medicine, Johns Hopkins University School of Medicine, Baltimore, Maryland ${ }^{6}$ Children's Hospital Association, Lenexa, KS

${ }^{7}$ Department of Pediatric Neurology, APHP, Bicêtre University Hospital, Le Kremlin-Bicêtre, France. ${ }^{8}$ Paris-Sud University, INSERM U 1169, Le Kremlin-Bicêtre, France.

${ }^{9}$ Department of Geography, University of Utah, Salt Lake City, Utah

${ }^{10}$ Division of Pediatric Neurology, Department of Pediatrics, University of Utah School of Medicine, Salt Lake City, Utah

${ }^{11}$ Brain and Spine Center, Primary Children's Hospital, Salt Lake City, Utah

${ }^{12}$ Primary Children's Center for Personalized Medicine, Salt Lake City, Utah

Running title: Vitamin D \& Latitude Predict ALD Brain Lesions

Word Count Abstract: 100

Word Count Manuscript: 1265

Character count title: 73 (w spaces)

Character count running title: 46 (w spaces)

Number of references: 17

Number of figures: 1

Number of tables: 2

Supplemental tables: 1

Corresponding Author:

Keith van Haren

Department of Neurology, Stanford University School of Medicine

750 Welch Rd, Ste 317

Palo Alto, California 
medRxiv preprint doi: https://doi.org/10.1101/2021.12.26.21268422; this version posted December 29, 2021. The copyright holder for this preprint (which was not certified by peer review) is the author/funder, who has granted medRxiv a license to display the preprint in perpetuity.

It is made available under a CC-BY-NC-ND 4.0 International license.

Disclosures: All authors have completed the ICMJE uniform disclosure form and declare that the study described in the submitted work was supported, in part, by the Child Neurology Foundation Scientific Award and NIH/NINDS K23NS087151; KV has received research grants from Bluebird bio and Minoryx for clinical trials in ALD participants, separate from the submitted work; consulting fees from Bluebird bio, Minoryx, Viking Therapeutics, Poxel, and Orpheris for ALD therapy development separate from the submitted work. He participates in advisory boards for Poxel (paid), Viking (paid), ALD Connect (unpaid), and the United Leukodystrophy Foundations (unpaid). GVR has received consulting fees from Bluebird bio, Viking Therapeutics, and Minoryx for therapy development outside the submitted work. JLB has received research support from Sanofi and Autobahn as well as consulting fees from Neurogene, Passage Bio, Takeda, and Autobahn all for work outside the submitted work. He is an unpaid board member at ALD Connect and wFluidx. No other relationships or activities that could appear to have influenced the submitted work. 
medRxiv preprint doi: https://doi.org/10.1101/2021.12.26.21268422; this version posted December 29, 2021. The copyright holder for this preprint (which was not certified by peer review) is the author/funder, who has granted medRxiv a license to display the preprint in perpetuity. It is made available under a CC-BY-NC-ND 4.0 International license .

\section{ABSTRACT}

A subset of boys with X-linked adrenoleukodystrophy (ALD) develop inflammatory demyelinating brain lesions. Risk factors are largely undefined. We used two independent cohorts to assess whether low vitamin D status predicts lesion development. In our first cohort, we measured 25hydroxyvitamin $D$ in 53 plasma samples from 20 pre-lesional ALD boys followed at two centers; half subsequently developed lesions. In our second cohort, we measured latitude (using home ZIP code) among 230 ALD boys in a database of 51 US pediatric hospitals; over half developed lesions. In regression models, low plasma vitamin D and northerly latitudes independently predicted ALD brain lesions. 
medRxiv preprint doi: https://doi.org/10.1101/2021.12.26.21268422; this version posted December 29, 2021. The copyright holder for this

preprint (which was not certified by peer review) is the author/funder, who has granted medRxiv a license to display the preprint in perpetuity.

It is made available under a CC-BY-NC-ND 4.0 International license .

\section{INTRODUCTION}

X-linked adrenoleukodystrophy (ALD) is caused by mutations in a single gene ( $A B C D 1)$ which encodes a peroxisomal fatty acid co-transporter, leading to accumulation of very long chain fatty acids in adrenal cortex, blood, and brain tissue. ${ }^{1}$ Thirty to forty percent of boys with ALD will develop a disease state termed cerebral ALD (CALD); incidence is concentrated in the first decade. ${ }^{2,3}$ cALD is marked by progressive inflammatory demyelinating brain lesions. Left untreated CALD culminates in a vegetative state and death within a few years of onset. ${ }^{4}$ Small, early-stage brain lesions can be halted with hematopoietic stem cell transplant. ${ }^{4,5}$ Although the presence of a pathogenic $A B C D 1$ variant confirms an ALD diagnosis, the risk for CALD is discordant in siblings or even identical twins. ${ }^{1}$ This suggests a role for environmental or epigenetic risk factors. Understanding etiology would be valuable for surveillance, treatment, and prevention.

Notably, ALD brain lesions share key similarities with multiple sclerosis lesions, including a predilection for the corpus callosum and an inflammatory demyelinating histology characterized by a leading edge of activated microglia, lipid-laden macrophages, and trailing lymphocytes. ${ }^{6} \mathrm{We}$ reasoned that shared histology could suggest shared risk factors. Lower levels of vitamin D exposure have been robustly linked to higher risk of multiple sclerosis diagnosis, subsequent brain lesions, and improved prognosis. ${ }^{7-11}$ Trials of vitamin D supplementation in multiple sclerosis have demonstrated modest benefits, including a reduction in the appearance of new brain lesions. ${ }^{12,13}$ Building on this premise, we investigated whether two established proxies for vitamin D exposure, plasma 25hydroxyvitamin D status and north-south latitude, were correlated with the risk of developing cALD brain lesions. 
medRxiv preprint doi: https://doi.org/10.1101/2021.12.26.21268422; this version posted December 29, 2021. The copyright holder for this preprint (which was not certified by peer review) is the author/funder, who has granted medRxiv a license to display the preprint in perpetuity.

\section{METHODS}

It is made available under a CC-BY-NC-ND 4.0 International license .

The Institutional Review Boards (IRB) of Stanford University, Kennedy Krieger Institute, Institut National de la Santé et de la Recherche Médicale (INSERM), and the University of Utah, exempted this study as non-human research.

To assess correlation of pre-morbid plasma 25-hydroxyvitamin D and subsequent development of cALD, we analyzed previously biobanked plasma samples collected as part of longitudinal clinical cohort studies of ALD boys at two centers (Kennedy Krieger Institute, Baltimore, Maryland, USA \& INSERM, Paris, France) between May 1, 1999 and November 8, 2012. All patients were followed with serial MRIs every 6-12 months to screen for brain lesions according to standard care guidelines. ${ }^{1}$ ALD brain lesions were defined as any gadolinium-enhancing white matter lesion on brain MRI. Plasma samples were collected longitudinally and stored at $-80^{\circ} \mathrm{C}$. Inclusion criteria for plasma analysis were: (i) molecular/biochemical diagnosis of ALD, (ii) male sex, (iii) age $<11$ years at sample collection (corresponding with period of maximal risk for $\mathrm{CALD}^{2,3}$ ), (iv) normal brain MRI prior to plasma collection, and (v) availability of plasma samples from at least two timepoints prior to study endpoint. Study endpoints were (i) identification of CALD brain lesion on MRI or (ii) no ALD brain lesion identified at time of last follow-up. We excluded samples collected after a brain lesion was identified. We measured 25-hydroxyvitamin D levels (Heartland Assays, Inc.) and C26:0 lipid levels (Kennedy Krieger Institute) using tandem mass spectrometry. Lipid levels were measured at the time of plasma collection. We used a two-tailed Mann-Whitney U-test to assess differences between groups (Prism Graphpad v8.4). We used a logistic regression analysis to estimate the odds of developing brain lesion based on each patient's average 25 -hydroxyvitamin D level (STATA v11).

To assess correlation of latitude and CALD, we determined the total number of ALD boys in the Pediatric Health Information System (PHIS) database. Patients had to be male, age $<19$ years, with a valid US ZIP code, and presenting between October 1, 2015 and June 30, 2019; with an ICD10 code for ALD, including E71520 - Childhood cerebral X-linked adrenoleukodystrophy; E71521 - Adolescent X-linked adrenoleukodystrophy; E71522 - Adrenomyeloneuropathy; E71528 - X-linked 
medRxiv preprint doi: https://doi.org/10.1101/2021.12.26.21268422; this version posted December 29, 2021. The copyright holder for this preprint (which was not certified by peer review) is the author/funder, who has granted medRxiv a license to display the preprint in perpetuity.

It is made available under a CC-BY-NC-ND 4.0 International license .

adrenoleukodystrophy NEC; and E71529 - X-linked adrenoleukodystrophy NOS. We assessed for the primary clinical outcome, the development of brain lesions, by the presence of an ICD9 or ICD10 code for at least one of the following categories indicating CNS involvement: bone marrow transplant/hematopoietic stem cell transplant; cerebral degeneration or neurological dysfunction; or cortical visual loss/blindness (full list in Supplemental Table 1). We used ZIP code to determine latitude; we collapsed latitude into $2^{\circ}$ ranges to allow a minimum of two ALD cases in each category. We excluded latitude ranges that had no ALD cases (19-24 north and $>49^{\circ}$ north). For each latitude range, we calculated the unadjusted probability of CALD among total ALD cases. We used a logistic regression model to calculate the probability of CALD among ALD patients adjusting for the size of

PHIS population. Finally, we modeled the relationship between latitude ranges and probability of CALD compared to ALD using logistic regression, adjusting for total PHIS population size in that latitude (SAS v9.4).

\section{RESULTS}

We identified 20 ALD boys with plasma samples collected at 53 timepoints over an average of $3.8 \pm 3.1$ years between first plasma collection and clinical endpoint. Ten boys developed brain lesions during observation (median Loes score 1.0). Although plasma samples were collected at similar ages in both groups, patients who never developed cALD were followed longer (Table 1). Average 25-hydroxyvitamin D levels were significantly lower among boys who developed cALD than those who did not (median 28.9 vs $36.6 \mathrm{ng} / \mathrm{ml}$ ); $p=0.019$ (Table 1). For each $10 \mathrm{ng} / \mathrm{mL}$ decrease in 25hydroxyvitamin D level, the odds ratio for developing cALD was 6.94 (95\% confidence interval, 1.05, 45.8); $p=0.044$. Fatty acid biomarkers associated with ALD were available for 16 patients; they were similar across groups (Table 1).

For latitude analysis, we identified 230 ALD boys across 28 states and $21^{\circ}$ of latitude; $57 \%$ of boys $(n=132)$ developed cALD. Each $2^{\circ}$ increase in latitude conferred an odds ratio of $1.17(95 \%$ confidence interval, 1.01, 1.35); $p=0.036$ for developing cALD (Table 2; Figure 1). 
medRxiv preprint doi: https://doi.org/10.1101/2021.12.26.21268422; this version posted December 29, 2021. The copyright holder for this

preprint (which was not certified by peer review) is the author/funder, who has granted medRxiv a license to display the preprint in perpetuity.

It is made available under a CC-BY-NC-ND 4.0 International license .

\section{DISCUSSION}

Using independent cohorts, we found that ALD boys with lower pre-morbid plasma levels of 25-hydroxyvitamin $\mathrm{D}$, or more northerly latitude of residence, were more likely to develop inflammatory brain lesions (CALD). These findings offer complementary lines of evidence implicating vitamin $\mathrm{D}$ and/or ultraviolet light exposure as a regulator of CALD risk.

We derived the concept of vitamin $D$ as risk factor for CALD based on histologic similarities between ALD and multiple sclerosis brain lesions. ${ }^{6,14}$ In multiple sclerosis, vitamin D's therapeutic mechanism is attributed to its role in immune homeostasis. ${ }^{12,14}$ Similar immunologic mechanisms are plausible in reducing risk of developing the inflammatory demyelination that similarly characterizes cALD. However, because the ALD genotype disrupts peroxisomal fatty acid metabolism and causes elevated very long chain fatty acid levels, our findings may implicate vitamin $D$ in mediating fatty acid metabolism and/or its role in immunologic homeostasis. ${ }^{15-17}$

Limitations of our study include the retrospective nature of our analyses and modest sample sizes, the latter of which limits our ability to assess for putative confounders. Although these analyses represent, to our knowledge, the first two assessments of vitamin D as a risk factor for CALD, prospective studies with or without intervention would further validate and refine the magnitude of risk associated with low vitamin D status in boys with an ALD genotype.

The advent of universal newborn screening for ALD has increased the number of ALD boys who can benefit from prospective MRI surveillance. Because ALD brain lesions rarely manifest before 2 years of age, widespread newborn screening could facilitate a trial of early life vitamin $D$ supplementation to test its potential as a preventive therapy against ALD brain lesions.

In summary, we describe two complementary lines of evidence implicating low vitamin D status as a risk factor for the development of brain lesions among ALD boys. Our findings also support the possibility of shared disease mechanisms in CALD and multiple sclerosis. 


\section{ACKNOWLEDGEMENTS}

JLB was supported by NIH grant 3UL1TR002538, and by the Bray Presidential Chair in Child Neurology research.

KV was supported by Child Neurology Society Scientific Award; NIH grant K23NS087151; the Tashia and John Morgridge Endowed Faculty Scholarship in Pediatric Translational Medicine of the Stanford Maternal \& Child Health Research Institute; gifts to the Lucile Packard Foundation, the Lenail-Yoler Family, the Adler Family, the Senkut Family, and from Arrivederci ALD.

\section{AUTHOR CONTRIBUTIONS}

KV and JLB conceptualized and designed the study and drafted the manuscript.

JLB, EMM, KV, TWC, JW analyzed the data and edited the manuscript for intellectual content. AM, GVR, and PA supervised and curated the longitudinal cohorts including specimen management, specimen selection, and associated clinical data.

\section{POTENTIAL CONFLICTS OF INTEREST}

Keith Van Haren: Dr Van Haren is conducting an NIH/NINDS funded (K23NS087151) pilot study of over-the-counter vitamin D supplementation in boys with adrenoleukodystrophy (NCT02595489) Jacob Wilkes: Nothing to report.

Ann B. Moser: Nothing to report.

Gerald V. Raymond: Nothing to report.

Troy Richardson: Nothing to report.

Patrick Aubourg: Nothing to report.

Timothy Collins: Nothing to report.

Ellen M. Mowry: Nothing to report.

Joshua L. Bonkowsky: Nothing to report. 


\section{References:}

1. Kemp S, Berger J, Aubourg P. X-linked adrenoleukodystrophy: clinical, metabolic, genetic and pathophysiological aspects. Biochim Biophys Acta. 2012;1822(9):1465-1474.

2. Huffnagel IC, Laheji FK, Aziz-Bose R, et al. The Natural History of Adrenal Insufficiency in XLinked Adrenoleukodystrophy: An International Collaboration. The Journal of clinical endocrinology and metabolism. 2019;104(1):118-126.

3. Bezman L, Moser HW. Incidence of X-linked adrenoleukodystrophy and the relative frequency of its phenotypes. Am J Med Genet. 1998;76(5):415-419.

4. Mahmood A, Raymond GV, Dubey P, Peters C, Moser HW. Survival analysis of haematopoietic cell transplantation for childhood cerebral X-linked adrenoleukodystrophy: a comparison study. Lancet Neurol. 2007;6(8):687-692.

5. Peters $\mathrm{C}$, Charnas LR, Tan Y, et al. Cerebral X-linked adrenoleukodystrophy: the international hematopoietic cell transplantation experience from 1982 to 1999 . Blood. 2004;104(3):881-888.

6. Pfeifenbring S, von Baumgarten L, Schuller U, et al. Biopsy findings of symptomatic cerebral X-linked adrenoleukodystrophy and histological differentiation from multiple sclerosis. Neuropathology and applied neurobiology. 2013.

7. Simpson S, Jr., Wang W, Otahal P, Blizzard L, van der Mei IAF, Taylor BV. Latitude continues to be significantly associated with the prevalence of multiple sclerosis: an updated metaanalysis. J Neurol Neurosurg Psychiatry. 2019;90(11):1193-1200.

8. Mowry EM, Krupp LB, Milazzo M, et al. Vitamin D status is associated with relapse rate in pediatric-onset multiple sclerosis. Ann Neurol. 2010;67(5):618-624.

9. Mowry EM, Waubant E, McCulloch CE, et al. Vitamin D status predicts new brain magnetic resonance imaging activity in multiple sclerosis. Ann Neurol. 2012;72(2):234-240.

10. Munger KL, Levin LI, Hollis BW, Howard NS, Ascherio A. Serum 25-hydroxyvitamin D levels and risk of multiple sclerosis. JAMA. 2006;296(23):2832-2838. 
medRxiv preprint doi: https://doi.org/10.1101/2021.12.26.21268422; this version posted December 29, 2021. The copyright holder for this preprint (which was not certified by peer review) is the author/funder, who has granted medRxiv a license to display the preprint in perpetuity. It is made available under a CC-BY-NC-ND 4.0 International license .

11. Kurtzke JF. The distribution of multiple sclerosis and other diseases. Acta Neurol Scand. 1966;42(2):221-243.

12. Sotirchos ES, Bhargava P, Eckstein C, et al. Safety and immunologic effects of high- vs lowdose cholecalciferol in multiple sclerosis. Neurology. 2016;86(4):382-390.

13. McLaughlin L, Clarke L, Khalilidehkordi E, Butzkueven H, Taylor B, Broadley SA. Vitamin D for the treatment of multiple sclerosis: a meta-analysis. J Neurol. 2018;265(12):2893-2905.

14. Pierrot-Deseilligny C, Souberbielle JC. Contribution of vitamin D insufficiency to the pathogenesis of multiple sclerosis. Therapeutic advances in neurological disorders. 2013;6(2):81-116.

15. Ji L, Gupta M, Feldman BJ. Vitamin D Regulates Fatty Acid Composition in Subcutaneous Adipose Tissue Through Elovl3. Endocrinology. 2016;157(1):91-97.

16. Lupton JR, Faridi KF, Martin SS, et al. Deficient serum 25-hydroxyvitamin D is associated with an atherogenic lipid profile: The Very Large Database of Lipids (VLDL-3) study. J Clin Lipidol. 2016;10(1):72-81 e71.

17. Nandi A, Wadhwani N, Joshi SR. Vitamin D deficiency influences fatty acid metabolism. Prostaglandins Leukot Essent Fatty Acids. 2019;140:57-63. 
medRxiv preprint doi: https://doi.org/10.1101/2021.12.26.21268422; this version posted December 29, 2021. The copyright holder for this preprint (which was not certified by peer review) is the author/funder, who has granted medRxiv a license to display the preprint in perpetuity.

It is made available under a CC-BY-NC-ND 4.0 International license.

Table 1. Demographics and plasma levels from 20 ALD boys at two academic medical centers. All boys had normal brain MRIs at the start of observation and were followed with serial MRIs to detect early-stage CALD. Clinical endpoints assigned according to whether patient developed CALD during period of observation.

\begin{tabular}{|c|c|c|c|c|c|}
\hline & \multicolumn{2}{|c|}{$\begin{array}{l}\text { Subsequent } \\
\text { cALD }\end{array}$} & \multicolumn{2}{|c|}{$\begin{array}{l}\text { no } \\
\text { CALD }\end{array}$} & \multirow[t]{2}{*}{$p$} \\
\hline & Median & $\begin{array}{l}\text { Interquartile } \\
\text { range }\end{array}$ & Median & $\begin{array}{l}\text { Interquartile } \\
\text { range }\end{array}$ & \\
\hline Patients meeting clinical endpoint (total $n=20$ ) & 10 & $\mathrm{n} / \mathrm{a}$ & 10 & $\mathrm{n} / \mathrm{a}$ & $\mathrm{n} / \mathrm{a}$ \\
\hline $\begin{array}{l}\text { Unique time points with plasma samples available } \\
\text { prior to clinical endpoint (minimum } 2 \text { per patient) }\end{array}$ & 21 & $\mathrm{n} / \mathrm{a}$ & 32 & $\mathrm{n} / \mathrm{a}$ & $\mathrm{n} / \mathrm{a}$ \\
\hline Age at time of plasma sample, years & 5.3 & $4.2-7.0$ & 6.6 & $4.2-7.8$ & 0.36 \\
\hline Age at endpoint, years & 6.7 & $5.5-7.7$ & 8.4 & $7.8-10.4$ & 0.02 \\
\hline $\begin{array}{l}\text { Duration of observation from first plasma sample to } \\
\text { endpoint, years }\end{array}$ & 2.0 & $1.2-2.3$ & 5.2 & $3.4-5.9$ & 0.007 \\
\hline $\begin{array}{l}\text { MRI lesion score (Loes score) at time of last MRI } \\
\text { (scale } 0-34 \text { ) }\end{array}$ & 1 & $1-1.8$ & 0 & 0 & $\mathrm{n} / \mathrm{a}$ \\
\hline C26:0, ( $\mathrm{n}=8$ patients with 18 plasma samples), ug/ml & 1.0 & $0.5-1.1$ & 0.6 & $0.4-1.0$ & 0.30 \\
\hline $\begin{array}{l}\text { C26:0-lysophosphatidylcholine, ( } \mathrm{n}=8 \text { patients with } 18 \\
\text { plasma samples), ug/ml }\end{array}$ & 0.3 & $0.2-0.4$ & 0.3 & $0.2-0.3$ & 0.48 \\
\hline $\begin{array}{l}\text { Plasma 25-hydroxyvitamin D, all timepoints }(\mathrm{n}=53) \text {, } \\
\mathrm{ng} / \mathrm{ml}\end{array}$ & 27.5 & $23.4-31.9$ & 33.8 & $29.3-42.8$ & 0.007 \\
\hline $\begin{array}{l}\text { Plasma } 25 \text {-hydroxyvitamin } D \text {, each patient's } \\
\text { timepoints averaged to a single value }(n=20), \mathrm{ng} / \mathrm{ml}\end{array}$ & 28.9 & $25.9-32.6$ & 36.6 & $33.1-42.0$ & 0.019 \\
\hline
\end{tabular}


medRxiv preprint doi: https://doi.org/10.1101/2021.12.26.21268422; this version posted December 29, 2021. The copyright holder for this preprint (which was not certified by peer review) is the author/funder, who has granted medRxiv a license to display the preprint in perpetuity.

It is made available under a CC-BY-NC-ND 4.0 International license .

Table 2: Incidence risk of CALD and latitude. CALD rates at each latitude range are shown before and after adjustments for Pediatric Healthy Information System (PHIS) population. The inclusion of latitude in the regression model significantly affected CALD rates. To protect patient confidentiality, we have not provided numerators (CALD patients) and denominators (all ALD patients) by latitude category since almost half the latitude ranges have either (i) fewer than 10 patients or (ii) fewer than 3 hospitals.

\begin{tabular}{|c|c|c|c|c|}
\hline Degrees Latitude ${ }^{*}$ & $\begin{array}{l}\text { Total PHIS } \\
\text { Population }\end{array}$ & $\begin{array}{l}\text { Unadjusted } \\
\text { probability of cALD } \\
\text { (\% with cALD) }\end{array}$ & $\begin{array}{l}\text { Adjusted }^{\star *} \\
\text { probability of CALD } \\
\text { - latitude excluded } \\
\text { from model } \\
\text { (\% with cALD) }\end{array}$ & $\begin{array}{l}\text { Adjusted }^{\star *} \\
\text { probability of cALD } \\
\text { - latitude included } \\
\text { in model } \\
\text { (\% with cALD) }\end{array}$ \\
\hline $25^{\circ}-26^{\circ}$ & 101,841 & $50.0 \%$ & $54.7 \%$ & $36.7 \%$ \\
\hline $27^{\circ}-28^{\circ}$ & 106,949 & $25.0 \%$ & $54.8 \%$ & $40.2 \%$ \\
\hline $29^{\circ}-30^{\circ}$ & 323,873 & $30.0 \%$ & $55.4 \%$ & $42.8 \%$ \\
\hline $31^{\circ}-32^{\circ}$ & 438,066 & $50.0 \%$ & $55.5 \%$ & $46.4 \%$ \\
\hline $33^{\circ}-34^{\circ}$ & 881,280 & $40.0 \%$ & $56.6 \%$ & $48.2 \%$ \\
\hline $35^{\circ}-36^{\circ}$ & 472,796 & $43.8 \%$ & $55.6 \%$ & $53.9 \%$ \\
\hline $37^{\circ}-38^{\circ}$ & 437,657 & $75.8 \%$ & $55.5 \%$ & $58.0 \%$ \\
\hline $39^{\circ}-40^{\circ}$ & $1,060,064$ & $56.0 \%$ & $57.2 \%$ & $58.5 \%$ \\
\hline $41^{\circ}-42^{\circ}$ & 698,861 & $72.1 \%$ & $56.1 \%$ & $64.2 \%$ \\
\hline $43^{\circ}-44^{\circ}$ & 156,815 & $50.0 \%$ & $54.8 \%$ & $69.9 \%$ \\
\hline $45^{\circ}-46^{\circ}$ & 51,321 & $0.0 \%$ & $54.6 \%$ & $73.4 \%$ \\
\hline $47^{\circ}-48^{\circ}$ & 72,553 & $60.0 \%$ & $54.6 \%$ & $76.3 \%$ \\
\hline Ollanced to oet at & of ALD in eac & ategory & & \\
\hline
\end{tabular}


medRxiv preprint doi: https://doi.org/10.1101/2021.12.26.21268422; this version posted December 29, 2021. The copyright holder for this preprint (which was not certified by peer review) is the author/funder, who has granted medRxiv a license to display the preprint in perpetuity. It is made available under a CC-BY-NC-ND 4.0 International license .

Figure 1. Graph of incidence risk of an ALD brain lesion compared to latitude. Each $2^{\circ}$ increase in latitude conferred an odds ratio of 1.17 (95\% confidence interval $1.01,1.35) ; p=0.036$ for developing CALD.

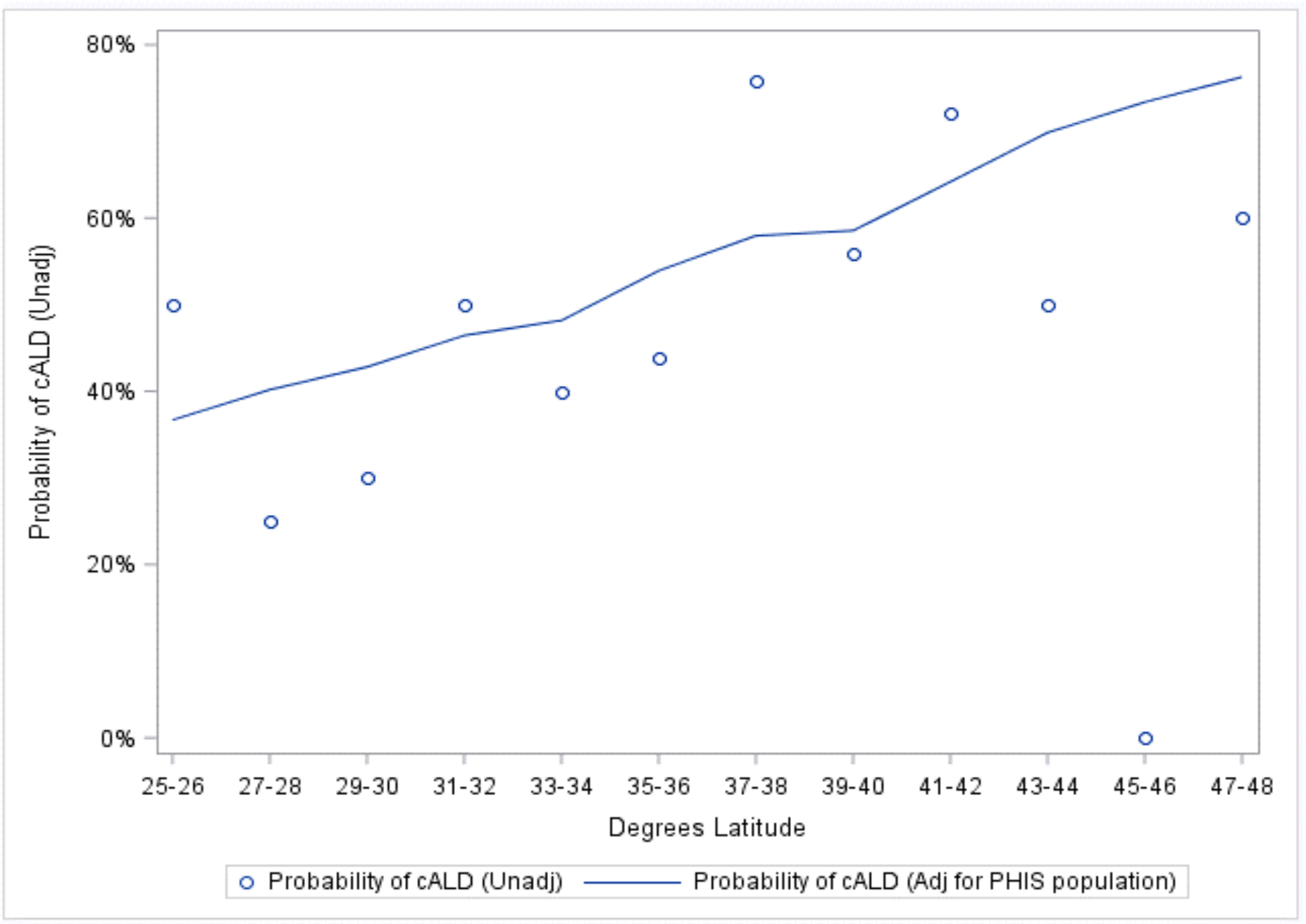


medRxiv preprint doi: https://doi.org/10.1101/2021.12.26.21268422; this version posted December 29, 2021. The copyright holder for this preprint (which was not certified by peer review) is the author/funder, who has granted medRxiv a license to display the preprint in perpetuity.

It is made available under a CC-BY-NC-ND 4.0 International license .

Supplemental Table 1. List of ICD10 codes used to determine presence of CALD.

\begin{tabular}{|c|c|c|c|}
\hline Code Type & Code & Description & cALD Grouping \\
\hline ICD-9-PCS-CD & 4100 & BONE MARROW TRANSPL NOS & Transplant \\
\hline ICD-9-PCS-CD & 4103 & ALLO MARROW TRANSPL NEC & Transplant \\
\hline ICD-9-PCS-CD & 4104 & AUTO STEM CELL TRANSPLAN & Transplant \\
\hline ICD-9-PCS-CD & 4105 & ALLOGENIC STEM CELL TRAN & Transplant \\
\hline ICD-9-PCS-CD & 4106 & CORD BLD STEM CELL TNSPL & Transplant \\
\hline ICD-9-CM-CD & 99685 & COMP MARROW TRANSPLANT & Transplant \\
\hline ICD-9-CM-CD & 99688 & COMP STEM CELL TRANSPL & Transplant \\
\hline ICD-9-CM-CD & V4281 & HX BONE MARROW TRANSPLNT & Transplant \\
\hline ICD-9-CM-CD & V4282 & HX PERIPH STEM CELL TRNS & Transplant \\
\hline ICD-10-PCS-CD & 30233Y0 & TRANSFUSION AUTOLOG HSC INTO PERIPH VEIN, PERQ & Transplant \\
\hline ICD-10-PCS-CD & 30233Y1 & TRANSFUSION NONAUT HSC INTO PERIPH VEIN, PERQ & Transplant \\
\hline ICD-10-PCS-CD & $30233 Y 2$ & TRANSFUS ALLOGEN REL HSC INTO PERIPH VEIN, PERQ & Transplant \\
\hline ICD-10-PCS-CD & $30243 G 1$ & TRANSFUS NONAUT BONE MARROW CENTRAL VEIN, PERQ & Transplant \\
\hline ICD-10-PCS-CD & $30243 G 2$ & TRANSFUS ALLOGEN RELATED BM CENTRAL VEIN, PERQ & Transplant \\
\hline ICD-10-PCS-CD & $30243 G 3$ & TRANSFUS ALLOGEN UNRELATED BM CENTRAL VEIN, PERQ & Transplant \\
\hline ICD-10-PCS-CD & $30243 Y 0$ & TRANSFUSION AUTOLOG HSC INTO CENTRAL VEIN, PERQ & Transplant \\
\hline ICD-10-PCS-CD & $30243 Y 1$ & TRANSFUSION NONAUT HSC INTO CENTRAL VEIN, PERQ & Transplant \\
\hline ICD-10-PCS-CD & $30243 Y 2$ & TRANSFUS ALLOGEN REL HSC INTO CENTRAL VEIN, PERQ & Transplant \\
\hline ICD-10-PCS-CD & $30243 Y 3$ & TRANSFUS ALLOGEN UNREL HSC IN CENTRAL VEIN, PERQ & Transplant \\
\hline ICD-10-CM-CD & T8600 & COMPLICATION BONE MARROW TRANSPLANT NOS & Transplant \\
\hline ICD-10-CM-CD & T8600 & COMPLICATION BONE MARROW TRANSPLANT NOS & Transplant \\
\hline ICD-10-CM-CD & T8601 & BONE MARROW TRANSPLANT REJECTION & Transplant \\
\hline ICD-10-CM-CD & T8601 & BONE MARROW TRANSPLANT REJECTION & Transplant \\
\hline ICD-10-CM-CD & T8602 & BONE MARROW TRANSPLANT FAILURE & Transplant \\
\hline ICD-10-CM-CD & T8602 & BONE MARROW TRANSPLANT FAILURE & Transplant \\
\hline ICD-10-CM-CD & T8609 & COMPLICATIONS BONE MARROW TRANSPLANT NEC & Transplant \\
\hline ICD-10-CM-CD & T8609 & COMPLICATIONS BONE MARROW TRANSPLANT NEC & Transplant \\
\hline ICD-10-CM-CD & Z48290 & ENCOUNTER AFTERCARE FOLLOW BONE MARROW TRANSPL & Transplant \\
\hline ICD-10-CM-CD & Z9481 & BONE MARROW TRANSPLANT STATUS & Transplant \\
\hline ICD-10-CM-CD & Z9484 & STEM CELLS TRANSPLANT STATUS & Transplant \\
\hline ICD-9-CM-CD & 3317 & CEREBRAL DEGEN IN DCE & Cerebral degeneration \\
\hline ICD-10-CM-CD & G3189 & DEGENERATIVE DISEASES NERVOUS SYSTEM NEC & Cerebral degeneration \\
\hline ICD-10-CM-CD & G319 & DEGENERATIVE DISEASE NERVOUS SYSTEM NOS & Cerebral degeneration \\
\hline ICD-9-CM-CD & 3670 & HYPERMETROPIA & Blindness, vision loss \\
\hline ICD-9-CM-CD & 3671 & MYOPIA & Blindness, vision loss \\
\hline ICD-9-CM-CD & 3693 & BLINDNESS NOS BOTH EYES & Blindness, vision loss \\
\hline ICD-9-CM-CD & 3694 & LEGAL BLINDNESS USA DEF & Blindness, vision loss \\
\hline ICD-9-CM-CD & 3698 & VISUAL LOSS ONE EYE NOS & Blindness, vision loss \\
\hline ICD-9-CM-CD & 3699 & VISUAL LOSS NOS & Blindness, vision loss \\
\hline ICD-9-CM-CD & 36720 & ASTIGMATISM NOS & Blindness, vision loss \\
\hline ICD-9-CM-CD & 36900 & BOTH EYES BLIND WHO DEF & Blindness, vision loss \\
\hline ICD-9-CM-CD & 36922 & SEVERE IMPAIR BOTH EYES & Blindness, vision loss \\
\hline ICD-9-CM-CD & 36960 & BLINDNESS ONE EYE & Blindness, vision loss \\
\hline ICD-10-CM-CD & H5202 & HYPERMETROPIA LEFT EYE & Blindness, vision loss \\
\hline ICD-10-CM-CD & H5203 & HYPERMETROPIA BILATERAL & Blindness, vision loss \\
\hline ICD-10-CM-CD & H5213 & MYOPIA BILATERAL & Blindness, vision loss \\
\hline
\end{tabular}


medRxiv preprint doi: https://doi.org/10.1101/2021.12.26.21268422; this version posted December 29, 2021. The copyright holder for this preprint (which was not certified by peer review) is the author/funder, who has granted medRxiv a license to display the preprint in perpetuity.

It is made available under a CC-BY-NC-ND 4.0 International license .

\begin{tabular}{|c|c|c|c|}
\hline ICD-10-CM-CD & H52202 & ASTIGMATISM NOS LEFT EYE & Blindness, vision loss \\
\hline ICD-10-CM-CD & H52203 & ASTIGMATISM NOS BILATERAL & Blindness, vision loss \\
\hline ICD-10-CM-CD & H52209 & ASTIGMATISM NOS EYE NOS & Blindness, vision loss \\
\hline ICD-10-CM-CD & H52223 & REGULAR ASTIGMATISM BILATERAL & Blindness, vision loss \\
\hline ICD-10-CM-CD & H527 & DISORDER REFRACTION NOS & Blindness, vision loss \\
\hline ICD-10-CM-CD & H540 & BLINDNESS BOTH EYES & Blindness, vision loss \\
\hline ICD-10-CM-CD & H543 & UNQUALIFIED VISUAL LOSS BOTH EYES & Blindness, vision loss \\
\hline ICD-10-CM-CD & H547 & VISUAL LOSS NOS & Blindness, vision loss \\
\hline ICD-10-CM-CD & H548 & LEGAL BLINDNESS AS DEFINED IN USA & Blindness, vision loss \\
\hline ICD-9-CM-CD & 3682 & DIPLOPIA & Eye disorders \\
\hline ICD-9-CM-CD & 3688 & VISUAL DISTURBANCES NEC & Eye disorders \\
\hline ICD-9-CM-CD & 3689 & VISUAL DISTURBANCE NOS & Eye disorders \\
\hline ICD-9-CM-CD & 3789 & EYE MOVEMENT DISORD NOS & Eye disorders \\
\hline ICD-9-CM-CD & 3798 & OTHER EYE DISORDERS & Eye disorders \\
\hline ICD-9-CM-CD & 36731 & ANISOMETROPIA & Eye disorders \\
\hline ICD-9-CM-CD & 36751 & ACCOMMODATION PARESIS & Eye disorders \\
\hline ICD-9-CM-CD & 36803 & REFRACTIVE AMBLYOPIA & Eye disorders \\
\hline ICD-9-CM-CD & 36813 & VISUAL DISCOMFORT & Eye disorders \\
\hline ICD-9-CM-CD & 36816 & PSYCHOPHYSIC VIS DISTURB & Eye disorders \\
\hline ICD-9-CM-CD & 37430 & EYELID PTOSIS NOS & Eye disorders \\
\hline ICD-9-CM-CD & 37489 & EYELID DISORDER NEC & Eye disorders \\
\hline ICD-9-CM-CD & 37710 & OPTIC ATROPHY NOS & Eye disorders \\
\hline ICD-9-CM-CD & 37775 & CORTICAL BLINDNESS & Eye disorders \\
\hline ICD-9-CM-CD & 37800 & ESOTROPIA NOS & Eye disorders \\
\hline ICD-9-CM-CD & 37810 & EXOTROPIA NOS & Eye disorders \\
\hline ICD-9-CM-CD & 37811 & MONOCULAR EXOTROPIA & Eye disorders \\
\hline ICD-9-CM-CD & 37815 & ALTERNATING EXOTROPIA & Eye disorders \\
\hline ICD-9-CM-CD & 37854 & SIXTH NERVE PALSY & Eye disorders \\
\hline ICD-9-CM-CD & 37887 & SKEW DEVIATION EYE & Eye disorders \\
\hline ICD-9-CM-CD & 37950 & NYSTAGMUS NOS & Eye disorders \\
\hline ICD-9-CM-CD & 37956 & NYSTAGMUS NEC & Eye disorders \\
\hline ICD-9-CM-CD & 37992 & EYE SWELLING OR MASS & Eye disorders \\
\hline ICD-10-CM-CD & $\mathrm{H} 02402$ & PTOSIS EYELID NOS LEFT EYELID & Eye disorders \\
\hline ICD-10-CM-CD & H0259 & DISORDERS AFFECTING EYELID FUNCTION NEC & Eye disorders \\
\hline ICD-10-CM-CD & $\mathrm{H} 4710$ & PAPILLEDEMA NOS & Eye disorders \\
\hline ICD-10-CM-CD & $\mathrm{H} 4720$ & OPTIC ATROPHY NOS & Eye disorders \\
\hline ICD-10-CM-CD & $\mathrm{H} 47293$ & OPTIC ATROPHY NEC BILATERAL & Eye disorders \\
\hline ICD-10-CM-CD & H47611 & CORTICAL BLINDNESS RIGHT SIDE BRAIN & Eye disorders \\
\hline ICD-10-CM-CD & $\mathrm{H} 47612$ & CORTICAL BLINDNESS LEFT SIDE BRAIN & Eye disorders \\
\hline ICD-10-CM-CD & H47619 & CORTICAL BLINDNESS BRAIN SIDE NOS & Eye disorders \\
\hline ICD-10-CM-CD & H5000 & ESOTROPIA NOS & Eye disorders \\
\hline ICD-10-CM-CD & H5005 & ALTERNATING ESOTROPIA & Eye disorders \\
\hline ICD-10-CM-CD & H5010 & EXOTROPIA NOS & Eye disorders \\
\hline ICD-10-CM-CD & H50112 & MONOCULAR EXOTROPIA LEFT EYE & Eye disorders \\
\hline ICD-10-CM-CD & H5015 & ALTERNATING EXOTROPIA & Eye disorders \\
\hline ICD-10-CM-CD & H50332 & INTERMITTENT MONOCULAR EXOTROPIA LEFT EYE & Eye disorders \\
\hline ICD-10-CM-CD & $\mathrm{H} 5043$ & ACCOMMODATIVE COMPONENT IN ESOTROPIA & Eye disorders \\
\hline ICD-10-CM-CD & H509 & UNSPECIFIED STRABISMUS & Eye disorders \\
\hline ICD-10-CM-CD & H518 & OTHER SPECIFIED DISORDERS OF BINOCULAR MOVEMENT & Eye disorders \\
\hline
\end{tabular}


medRxiv preprint doi: https://doi.org/10.1101/2021.12.26.21268422; this version posted December 29, 2021. The copyright holder for this preprint (which was not certified by peer review) is the author/funder, who has granted medRxiv a license to display the preprint in perpetuity.

It is made available under a CC-BY-NC-ND 4.0 International license .

\begin{tabular}{|c|c|c|c|}
\hline ICD-10-CM-CD & H53002 & UNSPECIFIED AMBLYOPIA, LEFT EYE & Eye disorders \\
\hline ICD-10-CM-CD & H53003 & UNSPECIFIED AMBLYOPIA, BILATERAL & Eye disorders \\
\hline ICD-10-CM-CD & H53009 & UNSPECIFIED AMBLYOPIA, UNSPECIFIED EYE & Eye disorders \\
\hline ICD-10-CM-CD & H53149 & VISUAL DISCOMFORT, UNSPECIFIED & Eye disorders \\
\hline ICD-10-CM-CD & H532 & DIPLOPIA & Eye disorders \\
\hline ICD-10-CM-CD & H538 & VISUAL DISTURBANCES NEC & Eye disorders \\
\hline ICD-10-CM-CD & H539 & VISUAL DISTURBANCE NOS & Eye disorders \\
\hline ICD-10-CM-CD & H5500 & NYSTAGMUS NOS & Eye disorders \\
\hline ICD-10-CM-CD & H5501 & CONGENITAL NYSTAGMUS & Eye disorders \\
\hline ICD-10-CM-CD & H5509 & OTHER FORMS NYSTAGMUS & Eye disorders \\
\hline ICD-10-CM-CD & H5702 & ANISOCORIA & Eye disorders \\
\hline ICD-10-CM-CD & H5704 & MYDRIASIS & Eye disorders \\
\hline ICD-10-CM-CD & H5711 & OCULAR PAIN RIGHT EYE & Eye disorders \\
\hline ICD-10-CM-CD & H578 & SPECIFIED DISORDERS EYE \& ADNEXA NEC & Eye disorders \\
\hline ICD-10-CM-CD & H579 & DISORDER EYE \& ADNEXA NOS & Eye disorders \\
\hline ICD-10-CM-CD & R441 & VISUAL HALLUCINATIONS & Eye disorders \\
\hline ICD-9-CM-CD & 7801 & HALLUCINATIONS & Neurologic disorders \\
\hline ICD-9-CM-CD & 7843 & APHASIA & Neurologic disorders \\
\hline ICD-9-CM-CD & 7845 & SPEECH DISTURBANCE NEC & Neurologic disorders \\
\hline ICD-9-CM-CD & 33183 & MILD COGN IMPAIRMENT & Neurologic disorders \\
\hline ICD-9-CM-CD & 78002 & TRANS ALTER AWARENESS & Neurologic disorders \\
\hline ICD-9-CM-CD & 78093 & MEMORY LOSS & Neurologic disorders \\
\hline ICD-9-CM-CD & 78097 & ALTERED MENTAL STATUS & Neurologic disorders \\
\hline ICD-9-CM-CD & 78451 & DYSARTHRIA & Neurologic disorders \\
\hline ICD-9-CM-CD & 78459 & SPEECH DISTURBANCE NEC & Neurologic disorders \\
\hline ICD-9-CM-CD & 78469 & SYMBOLIC DYSFUNCTION NEC & Neurologic disorders \\
\hline ICD-9-CM-CD & 79955 & FL \& EXEC FUNCT DEFICIT & Neurologic disorders \\
\hline ICD-10-CM-CD & G3184 & MILD COGNITIVE IMPAIRMENT SO STATED & Neurologic disorders \\
\hline ICD-10-CM-CD & R404 & TRANSIENT ALTERATION AWARENESS & Neurologic disorders \\
\hline ICD-10-CM-CD & R410 & DISORIENTATION NOS & Neurologic disorders \\
\hline ICD-10-CM-CD & R4182 & ALTERED MENTAL STATUS NOS & Neurologic disorders \\
\hline ICD-10-CM-CD & R41843 & PSYCHOMOTOR DEFICIT & Neurologic disorders \\
\hline ICD-10-CM-CD & R41844 & FRONTAL LOBE \& EXECUTIVE FUNCTION DEFICIT & Neurologic disorders \\
\hline ICD-10-CM-CD & R4189 & SX \& SIGN INVOLV COGNITIVE FUNC \& AWARENESS NEC & Neurologic disorders \\
\hline ICD-10-CM-CD & R440 & AUDITORY HALLUCINATIONS & Neurologic disorders \\
\hline ICD-10-CM-CD & R443 & HALLUCINATIONS NOS & Neurologic disorders \\
\hline ICD-10-CM-CD & R4701 & APHASIA & Neurologic disorders \\
\hline ICD-10-CM-CD & R4702 & DYSPHASIA & Neurologic disorders \\
\hline ICD-10-CM-CD & R471 & DYSARTHRIA \& ANARTHRIA & Neurologic disorders \\
\hline ICD-10-CM-CD & R479 & SPEECH DISTURBANCES NOS & Neurologic disorders \\
\hline ICD-10-CM-CD & R488 & SYMBOLIC DYSFUNCTIONS NEC & Neurologic disorders \\
\hline
\end{tabular}

